Tuncay Oral,

PhD (Counseling Psychological and Guidance), instructor, Department of Child Care and Youth Services, Pamukkale University, Çamlaraltı Mahallesi, University Cd., 11/A, Denizli, Turkey

\title{
INVESTIGATION OF FORGIVENESS LEVELS IN VOCATIONAL SCHOOL STUDENTS
}

Forgiveness plays an important role in being able to cope with the negative emotions that arise after the problems and the conflicts experienced by people. The study aims to investigate the forgiveness levels of vocational school students. In line with this aim, a total of 230 vocational school students consisting of 165 female (71.7\%) and 65 male (28.3\%) students were surveyed using Heartland Forgiveness Scale. Frequency, percent, mean and standard deviation analyses were used in this study. The research outcomes were computerized and tested with SPSS 16.0 program. According to the results of this research, there were 40 (17.4\%) students with the low level of forgiveness, 157 (68.3\%) respondents with the moderate level, and 33 (14.3\%) students with the high one. The mean scores of low forgiveness level $(x=14.11)$, moderate forgiveness level $(x=27.40)$, and high forgiveness level $(x=37.33)$ have been found. The fact that the students have a forgiveness average of 26.53 cannot be considered as negative, however, if the average score increases it will be better for students' psychological health. Some recommendations to increase this score have been presented in the paper.

Keywords: forgiveness, forgiveness levels, vocational school students.

\section{Introduction}

It is quite natural for the human, who is a social being, to have problems and conflicts in his/her interpersonal relationships. Depending on them, the person sometimes hurts other people and is sometimes hurt by them. In such situations, people sometimes are searching for revenge, but sometimes they try to forgive the "offender". According to Davis, Worthington, Hook and Hill (2013) the notion of forgiveness, which has been the subject of their study, had been investigated in the fields of philosophy and religion before it became studied in psychology. The analysis of studies on forgiveness in the psychology and psychological consultation fields shows that the researches before 1980s were considerably insufficient and limited [17]. The facts that the individuals that had researches in the field of psychology did not attach importance to positive psychological issues through a long period; the forgiveness was considered as a religious and philosophical structure; and accordingly it was regarded as an internal process, might be stated among the reasons for this late interest shown in the forgiveness concept $[10$; $13]$.

The review of the studies about forgiveness of the years that it was started to be discussed in the field of psychology shows that the emphasis was given to interpersonal forgiveness, or in other words forgiving others. Even, in these years, the notion of forgiveness has been conceptualized as forgiving others [1]. According to these researches, forgiveness plays an important role in being able to cope with the negative emotions that arise after the problems and conflicts experienced by people. The fact that the heartbroken person is able to forgive the opposing person is primarily related to having the knowledge of what forgiveness is or what it is not, and together with that knowing its benefits that are provided to the forgiving person. Experts that carry out scientific researches on forgiveness define the concept of forgiving others in different ways. Enright and The Human Development Study Group (1996), who is one of the leading researchers in this field, describes forgiving others as the individual's voluntarily leaving the feelings of anger, negative judgment, and disinterested behavior together with encouraging the un-deserved feelings such as love, generosity and compassion towards another person who have gratuitously hurt him/her. Similar to this definition, McCullough, Pargament and Thoresen (2000) describes forgiveness as individual's changing his/her revenge feelings to tolerance and empathy, with the purpose of fixing the damaged relationship with the person.

McCullough, Worthington and Rachal (1997) have dealt with motivations affecting the process of forgiving others in the model that they have developed. These motives mentioned in the model are the motives of revenge and avoidance. The person, who is hurt after an interpersonal offence action, tries to avoid the person who had offended him/her or tries to take revenge. According to this model, when an individual forgives someone, the basic motivations such as taking revenge and avoiding the person are diminished, while the desire of maintaining a positive relationship increases. The model mentions certain psychological determinants that make the forgiveness easy or difficult for the individual. Showing empathy, burdens related to the mistaken person, the belief in whether the mistake is intentional or not, and the severity of the mistake are some of these determinants. If the person who is offended has attributed negative meanings to the person that made the mistake, if he/she believes that the mistake is intentional, and if the mistake is considered 
as a significant one, he/she cannot show empathy, and thus, the possibility of seeking for a revenge increases and the possibility of forgiveness decreases [14]. When the literature was examined, it was found that forgiving others has positive correlations with the feelings of interpersonal cohesion, psychological well-being [20], psychological resiliency [3], self-compassion [16], satisfaction in life, positive emotions [19], empathy [12]. Health problems [11], fear [9], negative emotions, anger, anxiety [19] and depression [18] are variables that have negative correlations with forgiving others.

It is stated that together with many changes such as the physical area, the social and cultural environment, the conflicts in the interpersonal communication have been experienced during the university years; and therefore, the students pass through a period that is psychologically important [5]. In this perspective this study aims to investigate the forgiveness levels of vocational school students.

\section{Research Method}

\section{Research Group}

The data in the study was derived from the sample group consisting of a total of 230 vocational school students: 165 female $(71.7 \%)$ and 65 male $(28.3 \%)$ respondents studying at Pamukkale University/Kale Vocational School in 2016-2017 academic year, and were included in the research by simple random sampling method. The average age of the research group was 19.91.

\section{Data Collection Tools}

\section{Heartland Forgiveness Scale}

The Forgiveness of Others subscale of the scale, which was developed by Thompson et al. (2005) and adapted to Turkish by Bugay and Demir (2010), was used in this research. This subscale has 6 items, where 1, 3 and 5 Items are negative and must be scored in the reverse direction. The Cronbach Alpha internal consistency coefficient for the reliability of the Turkish form of the scale was calculated; and it was reported as .79 for the subscale of forgiveness others [1]. In this study, the internal consistency coefficient of Cronbach Alpha was found to be .82 as the result of the analysis on the data obtained from 230 vocational school students.

\section{Analysis of Data}

In line with the purpose of the study, the mean scores and standard deviations for all students' forgiveness scores were calculated to be able to divide them into three categories as low, moderate, and high based on their forgiveness levels. According to the statistical analysis performed, the mean score for the forgiveness level of all the students participating in the study was found to be 26.53 and its standard deviation was detected to be 8.36. In this case, the scores below 18.17 were considered to be the low level of forgiveness, the scores between 18.17 and 34.89 were called the moderate level of forgiveness, and the scores above 34.89 were regarded as the high level of forgiveness. In addition, frequency and percentages of students' forgiveness levels are calculated. The calculations have been tested via computers by using SPSS 16.0 software program.

\section{Results}

The analysis results of the forgiveness levels (low, moderate, high), frequency, percentage, mean and standard deviation of the vocational high school students are shown in table 1 .

Analysis Results for Forgiveness Levels (Low, Medium, High), Frequency, Percentage, Mean and Standard Deviation

\begin{tabular}{|c|c|c|c|c|c|}
\hline & Levels & Frequency & Percentage & Mean & $\begin{array}{c}\text { Standard } \\
\text { Deviation }\end{array}$ \\
\hline \multirow{3}{*}{ Forgiveness } & Low & 40 & $17.4 \%$ & 14.18 & 2.68 \\
of Others & Moderate & 157 & $68.3 \%$ & 27.40 & 5.97 \\
& High & 33 & $14.3 \%$ & 37.33 & 1.73 \\
& Total & 230 & $100 \%$ & 26.53 & 8.36 \\
\hline
\end{tabular}

As can be seen in Table 1, there are $40(17.4 \%)$ students with the low forgiveness level, 157 (68.3\%) students with the moderate forgiveness level, and 33 (14.3\%) students with the high forgiveness level. The mean scores of low forgiveness $(x=14.11)$, moderate forgiveness $(\mathrm{x}=27.40)$, and high forgiveness $(\mathrm{x}=37.33)$ have been found.

The histogram graphic results of the forgiveness points of vocational high school students are shown in figure 1 . 


\section{Histogram}

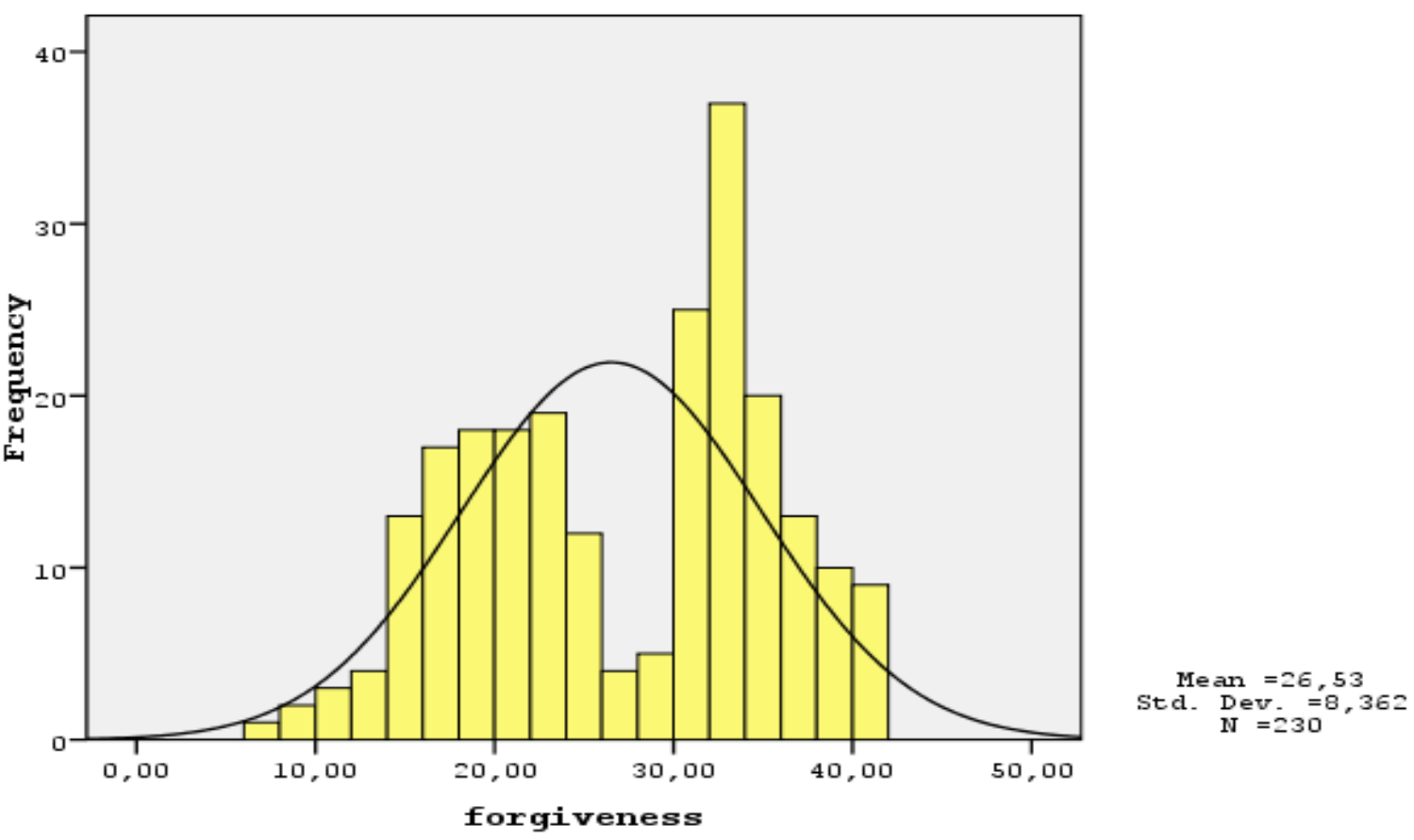

Fig.1. Histogram Graphic Results of the Forgiveness Points

As can be seen in figure 1, the students have a maximum score of 32-34 points. Students were found to have at least $6-8$ points. The highest score was 42 ; the lowest score is 6 points. The fact that the students have a forgiveness average of 26.53 cannot be cinsidered as a negative result. However, according to psychology literature, if the average score increases it will be better for them.

\section{Conclusions and Suggestions}

According to the results of this research, vocational school students have a moderate level of forgiving others. According to the literature, the increase of forgiveness may have a positive impact on the psychological health of the students. According to the research literature review, forgiveness has positive correlations with the feelings of interpersonal cohesion, psychological well-being [20], psychological resiliency [3], self-compassion [16], satisfaction in life, positive emotions [19], and empathy [12]. Health problems [11], fear [9], negative emotions, anger, anxiety [19] and depression [18] are variables that have negative correlations with forgiveness. It has been observed that the variables related to forgiveness in the literature support the research outcomes. According to the researches, forgiveness plays an important role in coping with the problems that people experience and the negative emotions that arise after the conflicts. Different opinions have been suggested about what is to forgive others in the field of literature, they seem to agree on what this concept is not. According to the researchers, forgetting the situation of being offended, tolerating and/or excusing the fault, and justifying the offending person is not forgiveness of others [6]. Additionally, forgiveness does not require compromising with the offending individual, trusting him/her, and waiving the legal rights $[10 ; 6]$.

Enright et al., (1996) states that "to be aware of the rumination of the other person's fault" is a very important element to forgive others in the process of forgiveness. Here the individual, who is to forgive, cannot reach to the stage of forgiveness, because he/she ruminates about the negative situation that exists. In the process of forgiving others, the individual takes a positive step by increasing his/her awareness. In the researches, it has been identified that rumination is related to negative variables such as anxious attachment [2], depressive feelings [22], experiential avoidance [15], and depression [2]. In the process of forgiving others, the individual becomes aware of rumination, takes steps towards forgiveness, and thus, abandons adverse situations such as anxious attachment, depressive feelings, experiential avoidance and depression. In other words, as the individual approaches towards forgiveness, he/she gets away from the negative situations.

According to Worthington's (1998) pyramid model, teaching counselees to forgive others' mistakes is an important way to deal with negative feelings and thoughts and to protect their well-being and repair their social relationships. According to Fitzgibbons (1998), forgiveness is considered as an effective process that one can use to cope with emotions such as anger, hostility and hatred; and through the act of forgiveness, the individual is liberated by giving up the feelings that control his/her life negatively. Shortly, it can be stated that the increasing of the level of forgiveness, which is found to be positively 
correlated with many positive variables such as satisfaction in life, positive emotions, interpersonal cohesion, psychological robustness, and psychological well-being; can reduce negative emotions and situations.

Regarding these results, certain recommendations can be suggested for the future research studies and experts in the field. Experts who provide psychological counseling services for individuals and groups may encounter counselees who experience negative emotions which result in personal conflicts and being hurt. Experts' emphasizing the concept of forgiveness while being involved in these conflicts and offences in the consultation process may help reducing negative emotional problems. In addition, experts may organize forgiveness training or

\section{REFERENCES}

1.Bugay, A. \& Demir, A. (2010). A Turkish version of Heartland Forgiveness Scale. Procedia-Social and Behavioral Sciences, 5, 1927-1931 [in English].

2.Burnette, J. L., Davis, D. E., Green, J. D., Worthington, E. L. \& Bradfield, E. (2009). Insecure attachment and depressive symptoms: The mediating role of rumination, empathy and forgiveness. Personality and Individual Differences, 46, 276-280 [in English].

3.Çapan, B. E. \& Arıcıoğlu, A. (2014). Psikolojik sağlamlığın yordayıcısı olarak affedicilik [Forgiveness as predictor of psychological resiliency]. E-International Journal of Educational Research, 5(4), 70-82 [in Turkish].

4.Davis, D. E., Worthington, E. L., Hook, J. N., \& Hill, P. C. (2013). Research on religion/spirituality and forgiveness: A meta-analytic review. Psychology of Religion and Spirituality, 5(4), 233 [in English].

5.Doğan, O., Doğan, S., Çorapçığlu, A., \& Çelik, G. (1994). Üniversite öğrencilerinde depresyon yaygınlığ ve bazı değişkenlerle ilişkisi [Depression prevalence and relation some variables in university students]. C. Ü. Tip Fakültesi Dergisi, 16(2), 148-151 [in Turkish].

6.Enright, R. D. (2001). Forgiveness Is A Choice: A Step-by-Step Process for Resolving Anger and Restoring Hope. American Psychological Association [in English].

7.Enright, R. D. \& The Human Development Study Group (1996). Counseling within the forgiveness triad: On forgiving, receiving forgiveness, and self forgiveness. Counseling and Values, 40(2), 107-126 [in English].

8.Fitzgibbons, R. (1998). Anger and the healing power of forgiveness: A psychiatrist's view. In R. Enright ve J. North (Eds), Exploring Forgiveness (pp. 63-74). Madison: University of Wisconsin [in English].

9.Freedman, S. R. \& Enright, R. D. (1996). Forgiveness as an intervention goal with incest survivors. Journal of Consulting and Clinical Psychology, 64, 983992 [in English].

10.Gordon, K. C., Baucom, D. H. \& Snyder, D. K. (2000). The use of forgiveness in marital therapy. Forgiveness: Theory, Research and Practice, 203-227 [in English]. psycho-education program for vocational school students. The study group of this study is composed of 230 students studying at a vocational school. It is believed that, repeating this study with a wider group of students by including the vocational school students from various countries will increase the probability of generalization of the results and help to find out learn whether these results are affected by cultural differences, if there are any. Finally, findings obtained within the scope of the research reflect an indirect observation obtained through a scale. The vocational school students' perceptions of forgiveness of others can be learned by using a qualitative methodology; and starting from that point, a deeper profile can be created for the vocational school students.

11.Lawler-Row, K. A., Hyatt-Edwards, L., Wuensch, K. L. \& Karremans, J. C. (2011). Forgiveness and health: The role of attachment. Personal Relationships, 18(2), 170-183 [in English].

12.Macaskill, A., Maltby, J. \& Day, L. (2002). Forgiveness of self and others and emotional empathy. The Journal of Social Psychology, 142(5), 663-665 [in English].

13.McCullough, M. E., Pargament, K. I. \& Thoresen, C. E. (2000). The psychology of forgiveness: History, conceptual issues and overview. In M. E. McCullough, K. I. Pargament ve C. E. Thoresen (Eds.), Forgiveness: theory, research and practice. New York: Guilford Press [in English].

14.McCullough, M. E., Worthington, E. L. \& Rachal, K. C. (1997). Interpersonal forgiving in close relationships. Journal of Personality and Social Psychology, 73(2), 321 [in English].

15.Neziroğlu, G. (2010). Ruminasyon, yaşantısal kaçınma ve problem çözme becerileri ile depresif belirtiler arasindaki ilişkilerin incelenmesi [An investigation on the relationship between rumination, experiental avoidance and problem solving skills in relation to depressive symptoms]. Yayımlanmamış yüksek lisans tezi, Hacettepe Üniversitesi, Sosyal Bilimler Enstitüsü, Ankara. [in Turkish].

16.Oral, T. (2016). Üniversite öğrencilerinin affetme düzeylerinin öz-anlayış, kişilerarası hataya ilişkin ruminasyon ve kişilik özellikleri açısından incelenmesi [The investigation of university students' forgiveness levels in terms of self-compassion, rumination about an interpersonal offense and personality traits]. Unpublished Doctoral Thesis, University of Necmettin Erbakan, Konya [in Turkish].

17.Scobie, E. D. \& Scobie, G. E. W. (1998). Damaging events: The perceived need for forgiveness. Journal for the Theory of Social Behaviour, 28(4), 373-402 [in English].

18.Skoda, A. M. (2011). The relation between selfcompassion, depression and forgiveness of other. Unpublished Master's Thesis, University of Dayton, Ohio [in English]. 
19.Thompson, L. Y., Snyder, C. R., Hoffman, L., Michael, S. T., Rasmussen, H. N., Billings, L. S. \& Roberts, D. E. (2005). Dispositional forgiveness of self, others, and situations. Journal of Personality, 73(2), 313-360 [in English].

20.Tse, W. S., \& Yip, T. H. J. (2009). Relationship among dispositional forgiveness of others, interpersonal adjustment and psychological well-being: Implication for interpersonal theory of depression. Personality and Individual Differences, 46(3), 365-368 [in English].
21.Worthington, E. L. (1998). The pyramid model of forgiveness: Some interdisciplinary speculations about unforgiveness and the promotion of forgiveness. In E. L. Worthington (Eds.), Dimensions of forgiveness: Psychological research and theological perspectives. Philadelphia: Templeton Foundation Press [in English].

22.Ysseldyk, R., Matheson, K. \& Anisman, H. (2007). Rumination: Bridging a gap between forgivingness, vengefulness, and psychological health. Personality and Individual Differences, 42(8), 1573-1584 [in English].

Тунджай Орал, кандидат психологічних наук, практичний психолог, викладач кафедри педагогіки, Університет Памуккале, вул. Юнівесіті Джаддесі, 11а, м. Денізлі, Туреччина

\section{ДОСЛІДЖЕННЯ РІВНІВ ВНУТРІШНЬОЇ ЗДАТНОСТІ ОСОБИСТОСТІ ПРОЩАТИ}

Уміння прощати відіграє важливу роль у здатності особистості боротися з негативними емоціями, які виникають у результаті виникнення проблемам чи конфліктів. Мета дослідження полягає у дослідженні рівнів внутрішньої здатності особистості прощзати. Відповідно до иієї мети було проведено експеримент, до якого було залучено 230 студентів професійно-технічних навчальних закладів: 165 дівчат (71,7\%) та 65 хлопців (28,3\%). Було використано особистісний опитувальник «Шкала внутрішньої здатності особистості прощати» за Хартлендом. Отримані дані було перевірено за допомогою програми SPSS 16.0. За результатами експерименту було виявлено 40 (17,4\%) студентів з низьким рівнем внутрішньої здатності прощати, 157 (68,3\%) респондентів з помірним рівнем та 33 (14,3\%) студентів - з високим. Було розраховано середні показники низького $(x=14,11)$, середнього $(x=27.40)$ та високого рівнів внутрішньої здатності промати $(x=37.33)$. Було зафіксовано найвищчй та найнижчий бали респондентів - 42 та 6 балів відповідно. Той факт, щяо більщість студентів мають середній рівень внутрішньої здатності прощати (26,53), не можна вважати негативною ознакою, однак, його підвищення матиме добрий вплив на психологічне здоров'я студентів. У статті подано деякі рекомендації щодо збільшення рівня внутрішньої спроможності прощати з метою впливу на психологічний стан особистості.

Ключові слова: прощення, рівні поблажливості, учні професійно-технічних навчальних закладів.

Submitted on June, 5, 2017 